\title{
Comparison of cultured and wild sea scallops Placopecten magellanicus, using behavioral responses and morphometric and biochemical indices
}

\author{
Martin Lafrance $^{1}$, Georges Cliche ${ }^{2}$, Geir A. Haugum ${ }^{3}$, Helga Guderley ${ }^{1, *}$ \\ ${ }^{1}$ Département de Biologie, Université Laval, Québec, Québec G1K 7P4, Canada \\ ${ }^{2}$ Ministère de l'Agriculture, des Pêcheries et de l'Alimentation, Direction de la recherche scientifique et technique, CP 658, \\ Cap-aux-Meules, Québec GOB 1BO, Canada \\ ${ }^{3}$ Marine Harvest Rogaland AS, 4130 Hjelmeland, Norway
}

\begin{abstract}
As the survival of juvenile scallops released onto the seabed is of critical importance in programs seeking to enhance scallop populations, the basis of the vulnerability of seeded cultured scallops needs to be understood. High mortality rates following seeding operations could reflect weaker predator escape responses by cultured scallops. Thus, we compared behavioral responses as well as morphometric and biochemical measurements of cultured and wild sea scallops Placopecten magellanicus (35 to $45 \mathrm{~mm}$ shell height) sampled in August 1999 in the Gulf of St. Lawrence, eastern Canada. Cultured scallops had larger somatic tissues and higher muscle energetic contents than their wild counterparts. This may reflect the more favorable temperatures and better food supply during suspension culture. When faced with the starfish predator Asterias vulgaris, cultured scallops responded with a greater number of claps, longer clapping period and faster recuperation of clapping performance. However, wild scallops had stronger shells and showed more intense escape responses (higher clapping rate) to the starfish. These differences contribute to making cultured scallops more vulnerable to predation by grasping predators (crabs) and asteroids.
\end{abstract}

KEY WORDS: Scallop $\cdot$ Placopecten magellanicus $\cdot$ Muscle $\cdot$ Escape response $\cdot$ Culture $\cdot$ Predation

Resale or republication not permitted without written consent of the publisher

\section{INTRODUCTION}

Juvenile mortality is a major factor determining the population dynamics of marine invertebrates, particularly in the case of broadcast spawners with a large reproductive output. High mortality due to predation can be a major obstacle to effective seeding of juveniles to enhance populations of heavily fished species. During culture of pectinids, juveniles are either collected by natural settlement onto artificial collectors or produced in a hatchery (Young-Lai \& Aiken 1986, Tremblay 1988, Naidu et al. 1989, Barbeau et al. 1996, Cliche \& Giguère 1998). Subsequent liberation of these juveniles into the natural habitat (during 'seedingranching' operations) exposes them to high rates of predation (Minchin 1991, Cliche et al. 1994, Barbeau et al. 1996, Hatcher et al. 1996). Since exposure to the threat of predation can lead to phenotypic defensive adaptations in many aquatic invertebrates (reviewed by Havel 1987), artificially reared juveniles may be more susceptible to predation if their defenses are less efficient than those of wild juveniles.

Despite the increasing reliance upon seeding juvenile scallops as a means of enhancing scallop production, surprisingly few studies have compared the performance of cultured and wild scallops. One such study shows that cultured Pecten maximus have weaker shells and are more susceptible to predation than wild $P$. maximus (Haugum et al. 1999). As the survival of juvenile scallops released onto the seabed is a critical determinant of the success of the 'seedingranching' strategy (Tremblay 1988, Naidu et al. 1989, 
Hatcher et al. 1996), the factors underlying the vulnerability of cultured scallops need to be understood. As a case in point, in the Îles-de-la-Madeleine, Gulf of St. Lawrence, eastern Canada, predation on seeded sea scallop Placopecten magellanicus is the main factor reducing their survival (Cliche et al. 1994).

Scallops are unique among bivalve mollusks in possessing an excellent swimming capacity which they use upon contact with predators (see Wilkens 1991). This response is most effective for escape from slowmoving predators such as starfish and gastropods. Cultured Placopecten magellanicus juveniles show a strong escape response to starfish (Barbeau \& Scheibling 1994a,b), suggesting that its escape responses are at least partly innate. Nonetheless, the nature of scallop swimming changes with size (Gould 1971, Dadswell \& Weihs 1990, Carsen et al. 1996). Smaller $P$. magellanicus swim in a spiral, whereas adults swim in more or less a straight line (Caddy 1968, Manuel \& Dadswell 1991, 1993). As scallop swimming responses are variable, we reasoned that the escape response to starfish (clapping rate, total number of claps until fatigue) may differ between wild and cultured juvenile P. magellanicus.

Reproductive investment and spawning markedly slow recuperation from exhaustive escape responses by adult Chlamys islandica and Euvola ziczac (Brokordt et al. 2000a,b). In both species, reproductive investment leads to a decline in muscle carbohydrate levels, as well as in muscle activities of glycolytic and mitochondrial enzymes, along with a decline in the capacity for recuperation from exhausting exercise. These changes suggest that the physiological status of the adductor muscle markedly influences its capacity for recuperation. As cultured and wild juvenile scallops have experienced different rearing densities, environmental conditions and manipulations, their physiological status is likely to differ, and this should affect their capacities for recuperation from exhausting escape responses.

In the present study, we compared cultured and wild scallops (35 to $45 \mathrm{~mm}$ shell height) at a period targeted for seeding by growers, to examine whether weaker behavioral and mechanical defenses and physiological status make cultured scallops more vulnerable to predation than their wild congeners present on the seeding grounds. We compared shell strength, escape responses, recuperation from exhausting escape responses, righting responses, anatomical measurements, levels of macromolecular reserves and enzyme activities in the muscle of wild and cultured juvenile Placopecten magellanicus. Our underlying hypothesis was that cultured scallops would perform less well than wild scallops in the parameters related to predation avoidance, since cultured scallops were grown in an environment without immediate contact with predators. We used the levels of macromolecular reserves and muscle metabolic capacities to assess whether the physiological capacities of muscle were linked with performance capacities in these wild and cultured juvenile scallops.

\section{MATERIALS AND METHODS}

Sampling and maintenance of scallops. The wild population studied was located south of the Îles-de-laMadeleine, in the 'Chaine-de-la-Passe' fishing area $\left(47^{\circ} 08^{\prime} \mathrm{N}, 61^{\circ} 43^{\prime} \mathrm{W}\right)$. A Digby drag with 2 standard baskets lined with $\operatorname{Vexar}^{\mathrm{TM}}$ (19 $\mathrm{mm}$ mesh) was used for sampling wild juvenile scallops at a depth of $30 \mathrm{~m}$.

The cultured scallops were collected and grown at Newhall (Fig. 1). In autumn 1997, spat settled into collector bags in which they grew until October 1998. Then they were transferred to pearl nets $(35 \mathrm{~cm}$ square base, with a $6 \mathrm{~mm}$ mesh netting) for $8 \mathrm{mo}$ of intermediate culture at a density of 100 ind. net ${ }^{-1}$. Thereafter, from June to August 1999, the juveniles were maintained at a density of $20 \mathrm{ind}$. net ${ }^{-1}$ (35 $\mathrm{cm}$ square base, with a mesh size of $9 \mathrm{~mm}$ ). From the beginning, cultured scallops fed on wild phytoplankton. At the time of study, the cultured scallops were 2 yr old.

After harvesting on August 24, the wild and cultured scallops were transported to the wet laboratory at the Cap-aux-Meules Research Station, where they were separately placed in continuously aerated $200 \mathrm{l}$ tanks and maintained at $12.5^{\circ} \mathrm{C}$ and in a natural photoperiod for $1 \mathrm{wk}$ before experimentation. We chose $12.5^{\circ} \mathrm{C}$ since it was halfway between the lagoon temperature $\left(19^{\circ} \mathrm{C}_{i}\right.$ Lafrance et al. 2002) and the bottom temperature $\left(7^{\circ} \mathrm{C}\right.$, measured with a thermograph attached to the dredge). Seawater was filtered $(1 \mu \mathrm{m})$ and UVsterilized. No food was supplied. Fecal material was removed daily and water was changed twice a week. Salinity ranged from 29.0 to $30.5 \%$ o during this study, both in the laboratory and at the collection sites.

To minimize the impact of size in our comparisons, we selected 76 individuals of 35 to $45 \mathrm{~mm}$ in shell height (maximum distance between the dorsal hinge and ventral margin; size range frequently used for seeding) for both the wild and cultured scallops. Scallops were tagged $\left(4 \times 8 \mathrm{~mm}\right.$ Hallprint ${ }^{\mathrm{TM}}$ labels glued on the upper valve using cyanoacrylate adhesive) to facilitate identification of individuals when measuring escape responses, righting responses, shell strength and biochemical and anatomic characteristics. We first measured the righting response $(\mathrm{n}=75$ for both wild and cultured scallops; missing datum for 1 scallop in each group), escape response and recuperation from exhausting escapes, then recorded the shell mass, 
height (dorsal-ventral), length (anterior-posterior diameter) and width (lateral diameter), and finally dissected the scallop to determine the mass of body components ( $\mathrm{n}=76$ for both groups of scallops). Escape responses for these scallops were evaluated over a $3 \mathrm{~d}$ period. Dissections were carried out after $1 \mathrm{wk}$ of recuperation from the escape response tests. The adductor muscle of each scallop was frozen on dry ice immediately after dissection and was maintained on dry ice for approximately 1 mo before transfer to $-80^{\circ} \mathrm{C}$ at Université Laval. Other soft tissues (including mantle, gills, digestive tract and a tiny gonad) were dried to constant mass at $60^{\circ} \mathrm{C}$. The shells were refrigerated in plastic bags containing seawater for maximally $10 \mathrm{~d}$ until determination of shell strengths at Université Laval. Additional scallops with a larger range of shell heights (25 to $51 \mathrm{~mm} ; \mathrm{n}=73$ and 64 for wild and cultured scallops, respectively) were used for shell strength determinations. Righting responses were also determined for individuals measuring 45 to $55 \mathrm{~mm}$ ( $\mathrm{n}=30$ for both groups of scallops). Several anatomical indices were calculated to examine the relative changes of the variables measured. Muscle indices 1 (muscle mass/mass of total soft tissues minus muscle mass) and 2 (muscle mass/shell mass), a condition index (mass of total soft tissues/shell volume) and the aspect ratio [(shell length/shell height $) \times 100]$ are presented in Table 1 . The shell volume $[\pi \times($ height $/ 2) \times$ $($ length $/ 2) \times($ width $\times 0.38)$ ] was estimated by modifying the formula for the volume of a cone with an empirically estimated constant (0.38) assessed from the water displaced by a clay model of a shell of known dimensions.

Behavioral tests. Evaluation of escape responses: Individual scallops were placed in $33 \times 28 \times 12 \mathrm{~cm}$ trays containing $\sim 61$ of filtered seawater at $12^{\circ} \mathrm{C}$. Scallops were allowed at least $2 \mathrm{~min}$ in the basin before stimulation (Ordzie \& Garofalo 1980). We stimulated swimming of a scallop by touching it with the arm of a starfish (Asterias vulgaris, 11 to $15 \mathrm{~cm}$ in diameter), and then recorded the time and number of valve adductions (claps) until fatigue. We also noted the maximal number of claps in a series during the second and third days of experimentation. In contrast to adults, juvenile Placopecten magellanicus do not consistently close their valves when exhausted, so fatigue was defined by the scallops' incapacity to clap within 1 min of the previous clap. Once the scallop was exhausted, it was left in its aerated basin for $15 \mathrm{~min}$. Then the escape response was quantified a second time. Preliminary tests established that 15 min was sufficient for partial recuperation of escape response capacity. If no claps occurred within 2 min of stimulation, the observation was stopped. Seawater in the trays was replaced before starting a test with another scallop.

The Asterias vulgaris used to elicit the escape responses had been harvested in the lagoon Le Bassin (south of the Îles-de-la-Madeleine; Fig. 1) and maintained in a tank containing $180 \mathrm{l}$ of filtered and continuously aerated seawater. The starfish were starved for at least $24 \mathrm{~h}$ before the experiments, to standardize their hunger level (Elner \& Jamieson 1979, Barbeau \& Scheibling 1994b). The starfish used in a particular escape response test were haphazardly chosen from 20 individuals. The same starfish was used for the 2 escape response tests of a given scallop.

Righting responses: Righting responses were quantified in two $58 \times 118 \times 60 \mathrm{~cm}$ tanks containing $100 \mathrm{l}$ of filtered and aerated seawater. No gravel was provided. The scallops were placed with their upper (left) valve 
on the bottom of the aquarium. All scallops were upside-down at the onset of the test. The number of scallops that had righted themselves was determined at 5 min intervals until at least $95 \%$ of the scallops had righted themselves. Thus, the precision for the estimate of the righting time of each scallop was within $5 \mathrm{~min}$. One tank was used for the cultured scallops and a second for the wild scallops.

Evaluation of shell strength. An Instron Model TT Universal testing instrument with a force range of 0.5 to $10000 \mathrm{~kg}$ ( $5 \mathrm{~g}$ precision) was used to crush the scallop shells. A $2 \mathrm{~mm}$ steel pin with a shape similar to that of the tip of a crab claw was applied at the region normally attacked by crabs (Elner \& Jamieson 1979). We placed the pin on the left valve in a position $1 \mathrm{~cm}$ ventral to the ligament, where growth lines typically became visible. We used this approach to simulate the pressure applied during an attack by a crab.

Muscle protein and carbohydrate concentrations. All biochemical determinations examined the phasic portion of the adductor muscle. Total protein concentrations were measured using the bicinchoninic acid method according to Smith et al. (1985), with bovine serum albumin (BSA) as a standard. The total content of carbohydrates was determined using the phenolsulfuric acid method of Dubois et al. (1956), as modified by Martinez (1991). One aliquot of homogenate was resuspended (1:11) in trichloracetic acid $(10 \%)$, placed in an incubator at $65^{\circ} \mathrm{C}$ for $60 \mathrm{~min}$, cooled and centrifuged for $15 \mathrm{~min}$ at $4342 \times g$ at $4^{\circ} \mathrm{C}_{i} 2 \mathrm{ml}$ of phenol (>99.5\%) was added to $1 \mathrm{ml}$ of supernatant; $5 \mathrm{ml}$ sulfuric acid (95\%) was then added. After vigorous vortexing, the mixture was heated at $80^{\circ} \mathrm{C}$ for $20 \mathrm{~min}$. After cooling, the absorbance at $490 \mathrm{~nm}$ was determined using a UV-Vis spectrophotometer (Beckman DU-640). Oyster glycogen was used as a standard.

Enzyme assays. Muscle was homogenized in 9 volumes $(\mathrm{m} / \mathrm{v})$ of ice-cold imidazole- $\mathrm{HCl} 50 \mathrm{mM}, 2 \mathrm{mM}$ EDTA-Na, 5 mM EGTA (ethyleneglycol tetraacetic acid), $150 \mathrm{mM} \mathrm{KCl}, 0.1 \%$ (v/v) Triton $\mathrm{x}-100$ and $1 \mathrm{mM}$ dithiothreitol. Homogenization occurred on ice using a Polytron (Brinkman Instruments) for $3 \times 20 \mathrm{~s}$ periods separated by $20 \mathrm{~s}$ cooling periods. The $\mathrm{pH}$ was 6.6 for extracts used to measure octopine dehydrogenase $(\mathrm{ODH})$ and arginine kinase (AK), and $\mathrm{pH} 7.2$ with the addition of $20 \mathrm{mM} \mathrm{NaF}$ for phosphofructokinase (PFK), glycogen phosphorylase (GP) and citratre synthase (CS). A portion of this extract was centrifuged at $10000 \times g$ at $4^{\circ} \mathrm{C}$ for the assay of PFK and GP.

Enzyme activities were measured using a UV-Vis spectrophotometer (Beckman DU-640), with assay temperature controlled at $12.5^{\circ} \mathrm{C}$ by a refrigeratingcirculating water bath (Haake). Enzyme assays were followed at $340 \mathrm{~nm}$ to note changes in the concentra- tion of $\mathrm{NAD}(\mathrm{P}) \mathrm{H}$, except in the case of $\mathrm{CS}$, which was followed at $412 \mathrm{~nm}$ to detect the transfer of sulfhydryl groups to 5,5'dithiobis-2-nitrobenzoic acid (DTNB). The micromolar extinction coefficients for $\mathrm{NAD}(\mathrm{P}) \mathrm{H}$ and DTNB were 6.22 and $13.6 \mathrm{~cm}^{2} \mu \mathrm{mol}^{-1}$, respectively. All enzyme assays were carried out in duplicate. Enzyme activities were expressed in international units ( $\mu \mathrm{mol}$ of substrate transformed to product $\mathrm{min}^{-1}$; U) $\mathrm{g}^{-1}$ wet mass, units $\mathrm{mg}^{-1}$ protein and as total units in the adductor muscle. We adapted enzyme assay conditions from studies on adult Placopecten magellanicus by de Zwaan et al. (1980) and Stewart et al. (1992), as follows:

Glycogen phosphorylase a (EC 2.4.1.1 GP): $50 \mathrm{mM}$ imidazole, $80 \mathrm{mM} \mathrm{KH}_{2} \mathrm{PO}_{4}, 5 \mathrm{mM} \mathrm{Mg}$-acetate, $2.5 \mathrm{mM}$ EDTA, $0.6 \mathrm{mM}$ NADP, $0.8 \mathrm{mM}$ AMP, $0.5 \mathrm{mM}$ cyclic AMP, $4 \mu \mathrm{M}$ glucose-1,6-bisphosphate, $10 \mathrm{mg} \mathrm{ml}^{-1}$ glycogen (omitted for controls), pH 7.5. Glucose-6phosphate dehydrogenase and phosphoglucomutase activities were present in excess.

Phosphofructokinase (EC 2.7.1.11 PFK): $50 \mathrm{mM}$ Tris$\mathrm{HCl}, 50 \mathrm{mM} \mathrm{KCl}, 5 \mathrm{mM} \mathrm{Mg}$-acetate, $1 \mathrm{mM}$ ATP, $0.8 \mathrm{mM}$ AMP, $0.2 \mathrm{mM}$ NADH, $0.08 \mathrm{mM}$ fructose-2, 6bisphosphate, $1 \mathrm{mM}$ fructose-6-phosphate (omitted for controls), pH 7.5. Excess levels of aldolase, triosephosphate isomerase and glycerol-3-phosphate dehydrogenase were used.

Octopine dehydrogenase (EC 1.5.1.11 ODH): $50 \mathrm{mM}$ imidazole-HCl, 2 mM EDTA-Na $\mathrm{Na}_{2}, 5 \mathrm{mM}$ EGTA, $1 \mathrm{mM}$ $\mathrm{KCN}, 0.2 \mathrm{mM} \mathrm{NADH}, 5 \mathrm{mM}$ pyruvate-Na, $6 \mathrm{mM}$ L-arginine (omitted for controls), $\mathrm{pH}$ 6.6.

Arginine kinase (EC 2.7.3.3 AK): $50 \mathrm{mM}$ imidazole$\mathrm{HCl}_{1} 5 \mathrm{mM} \mathrm{MgCl}, 0.4 \mathrm{mM}$ ADP, $10 \mathrm{mM}$ glucose, $0.6 \mathrm{mM}$ NADP, $5 \mathrm{mM}$ phosphoarginine (omitted for controls), $\mathrm{pH}$ 6.6. Excess levels of hexokinase and glucose-6-phosphate dehydrogenase were used.

Citrate synthase (EC 4.1.3.7 CS): $75 \mathrm{mM}$ Tris, $0.4 \mathrm{mM}$ acetyl CoA, $0.25 \mathrm{mM}$ DTNB, $0.5 \mathrm{mM}$ oxaloacetate (omitted for controls), pH 8.0.

Chemicals. Metabolites and coupling enzymes were purchased from Sigma, Roche Diagnostics and ICN Pharmaceuticals. All other reagents were analytical grade.

Statistical analyses. Statistical analyses were performed using SAS software package (SAS 1999). Prior to the analyses, the data were tested for normality using the Shapiro-Wilk's $W$-test (Zar 1984); homoscedasticity was verified by graphically examining the distribution of the variance residues. A probability level of 0.05 was used.

Anatomical measurements, muscle levels of carbohydrates, proteins and enzymes were compared either by Student's $t$-test or Mann-Whitney $U$-test (Zar 1984), depending on the normality of the data. The shell strengths were compared using analyses of 
covariance (ANCOVA) to assess the effect of the shell mass on the slope of the regression line (Snedecor \& Cochran 1989). Residual mean squares from the 2 regression lines (i.e. wild and cultured separately) were first compared by the 2-tailed F-test to ensure the equality of residual variances. Then, slopes were compared by testing the significance of the interaction term (origin $\times$ shell mass) within the ANCOVA. We present non-transformed data (see Fig. 2) to facilitate interpretation since the relation between slopes was very similar to the appropriate log-transformed data.

ANOVA following the GLM procedure tested the effects of the independent factors (origin and day of study) and their interactions on escape response parameters. A total lack of response after the $15 \mathrm{~min}$ recuperation was observed for 2 cultured and 4 wild scallops. These individuals were excluded from those analyses. Moreover, after recuperation, certain scallops ( $\leq 4)$ showed responses beyond $200 \%$ of their initial values for a given escape parameter and were eliminated from the corresponding analysis. Data were log, square root or reciprocally transformed when necessary to achieve normality and homoscedasticity. Untransformed values are reported in the tables and figures.

To assess the impact of the biochemical and anatomic parameters upon the escape responses, we carried out a multi-step analysis. We initially selected the anatomic (full data set) and biochemical (subset of 56 scallops) variables that least inflated the variance of the parameters quantified during the escape responses, using the REG/vif collin procedure of SAS (1999). Then, we focused on the subset of 56 individuals. The variables previously selected were subjected to a multiple stepwise regression and significantly correlated variables (slstay $=0.15$ ) were retained to perform an ANCOVA with origin and day of study as factors.

\section{RESULTS}

\section{Anatomical parameters}

For a given shell height, the length, width, volume and aspect ratio were greater for cultured than wild scallops (Table 1). Shell mass did not differ between the 2 groups of scallops. All soft tissue masses (phasic and catch adductor muscle, digestive gland, other soft parts) were heavier in cultured than wild scallops. A condition index evaluating the total soft tissue mass relative to shell volume was also greater in cultured than wild scallops. Water content of the soft tissues (without the digestive gland and muscle) was greater in wild scallops. Shell strength was greater for wild scallops, particularly for larger scallops (Fig. 2). The regression lines from tagged scallops (35 to $45 \mathrm{~mm}$ of shell height) and scallops from a wider shell height range (25 to $51 \mathrm{~mm}$ ) indicate a faster increase in shell strength with shell mass for wild scallops (Table 2).

\section{Behavioral responses}

Wild scallops clapped at a higher rate, exhausted faster (could not clap within $1 \mathrm{~min}$ ) and stayed shut for longer periods than cultured scallops (Table 3). In contrast, cultured scallops made more claps before exhaustion. After 15 min of recuperation from exhaustive escape responses, the cultured scallops maintained their greater number of claps and longer clapping time and, showed a higher maximum number of claps in a series. Wild scallops maintained their higher clapping rate after recuperation.

Table 1. Placopecten magellanicus. Anatomical measurements of wild and cultured sea scallops $P$. magellanicus ( 35 to $45 \mathrm{~mm}$ ) used in behavioral and biochemical comparisons (mean, SE in parentheses) $(n=76)$. When not specified, fresh tissue masses are given; $\mathrm{p}$-values are from Student's $t$-tests, or from Mann-Whitney $U$-tests when the data were not normally distributed. $T_{\mathrm{m}}=$ mass of total soft tissues $\left[M_{\mathrm{m}}+D_{\mathrm{m}}+O_{\mathrm{m}}\right]$

\begin{tabular}{|lccc|}
\hline Variable & Cultured & Wild & $\mathrm{p}$ \\
\hline Shell characteristics & & & \\
$\quad$ Height $\left(S_{\mathrm{h}}\right), \mathrm{mm}$ & $40.1(0.3)$ & $40.2(0.3)$ & 0.80 \\
Length $\left(S_{\mathrm{l}}\right), \mathrm{mm}$ & $39.1(0.3)$ & $38.1(0.3)$ & 0.026 \\
Width $\left(S_{\mathrm{w}}\right), \mathrm{mm}$ & $10.1(0.1)$ & $8.9(0.1)$ & $<0.0001$ \\
Volume $\left(S_{\mathrm{v}}\right), \mathrm{cm}^{3}$ & $4.8(0.1)$ & $4.1(0.1)$ & $<0.0001$ \\
Aspect ratio $\left[\left(S_{\mathrm{l}} / S_{\mathrm{h}}\right) \times 100\right]$ & $97.4(0.3)$ & $94.8(0.4)$ & $<0.0001$ \\
Mass $\left(S_{\mathrm{m}}\right), \mathrm{g}$ & $3.510(0.080)$ & $3.604(0.090)$ & 0.36 \\
Soft tissue masses $\left(T_{\mathrm{m}}\right), \mathrm{g}$ & & & \\
Adductor muscle, phasic & $0.982(0.025)$ & $0.601(0.015)$ & $<0.0001$ \\
Adductor muscle, catch & $0.105(0.003)$ & $0.087(0.002)$ & $<0.0001$ \\
Adductor muscle, total $\left(M_{\mathrm{m}}\right)$ & $1.086(0.027)$ & $0.688(0.017)$ & $<0.0001$ \\
Digestive gland $\left(D_{\mathrm{m}}\right)$ & $0.277(0.008)$ & $0.146(0.004)$ & $<0.0001$ \\
Other soft tissues, wet $\left(O_{\mathrm{m}}\right)$ & $1.482(0.034)$ & $1.205(0.025)$ & $<0.0001$ \\
Other soft tissues, dry & $0.190(0.004)$ & $0.140(0.003)$ & $<0.0001$ \\
Water content of other & $87.2(0.1)$ & $88.3(0.1)$ & $<0.0001$ \\
soft tissues, \% & & & \\
Muscle index $1\left[M_{\mathrm{m}} /\left(D_{\mathrm{m}}+O_{\mathrm{m}}\right)\right]$ & $61.9(0.7)$ & $51.0(0.7)$ & $<0.0001$ \\
Muscle index 2 $\left(M_{\mathrm{m}} / S_{\mathrm{m}}\right)$ & $31.1(0.4)$ & $19.3(0.3)$ & $<0.0001$ \\
Condition index & $59.7(0.5)$ & $49.9(0.5)$ & $<0.0001$ \\
[( $\left.\left.T_{\mathrm{m}} / S_{\mathrm{v}}\right) \times 100\right], \mathrm{g} \mathrm{cm}{ }^{-3}$ & & & \\
\hline
\end{tabular}




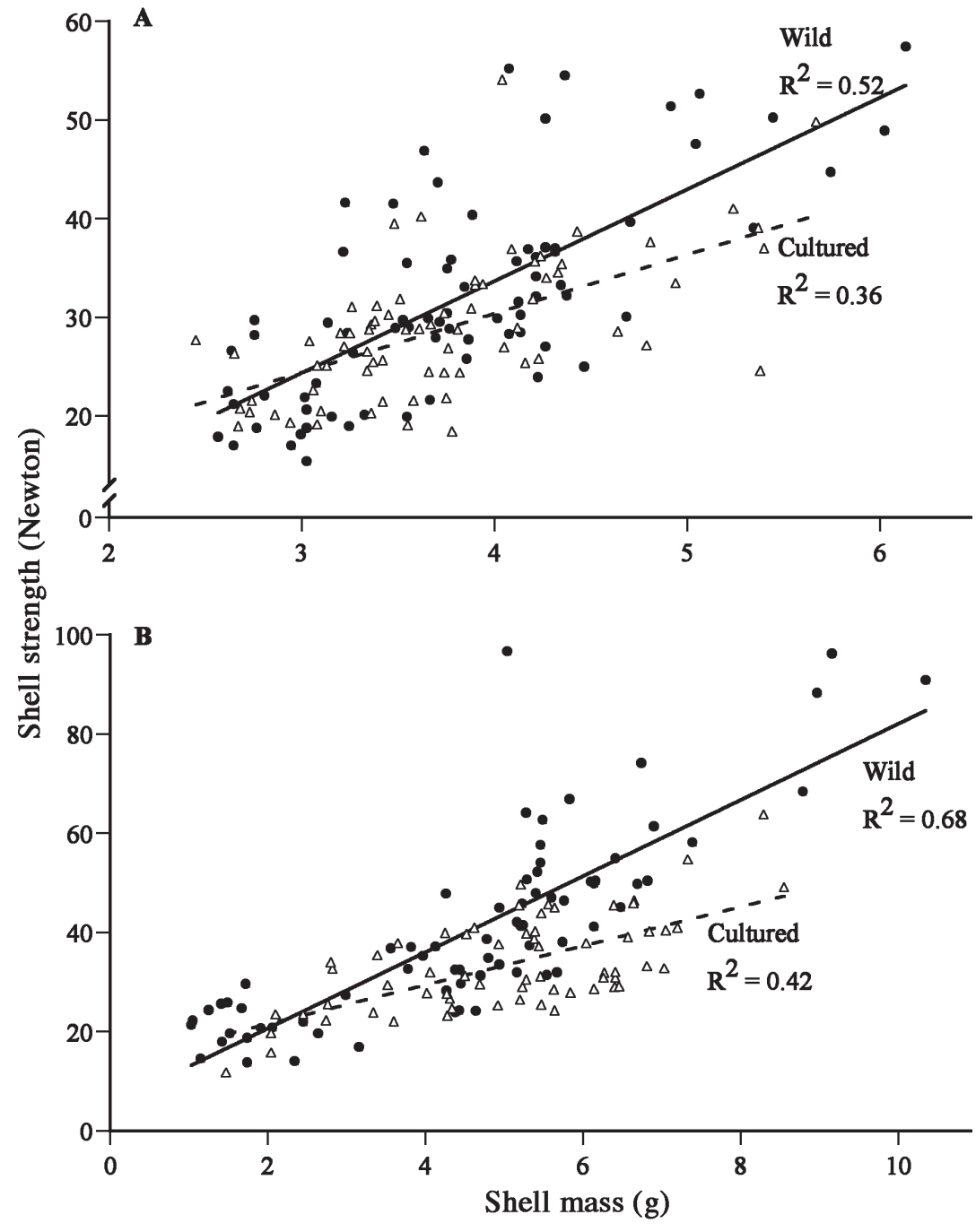

Fig. 2. Placopecten magellanicus. Relationship between the pressure causing shell breaking (strength) and shell mass for wild and cultured sea scallops. (A) Scallops (35 to $45 \mathrm{~mm}$ ) used in all comparisons; $\mathrm{n}=75$ and 72 for wild and cultured scallops, respectively. (B) Other scallops (25 to $51 \mathrm{~mm}$ ) used to examine shell strength; $n=73$ and 64 for wild and cultured scallops, respectively

Table 2. Placopecten magellanicus. ANCOVA statistics on log-transformed shell strength for 35 to 45 and 25 to $51 \mathrm{~mm}$ wild and cultured sea scallops with shell mass as the covariate. Log transformations were made to ensure normality and homoscedasticity of residuals

\begin{tabular}{|c|c|c|c|c|c|}
\hline & df & SS & MS & $F$ & $\mathrm{p}$ \\
\hline \multicolumn{6}{|l|}{ 35-45 mm scallops } \\
\hline Equality of slopes & 1 & 0.031 & 0.031 & 4.01 & 0.047 \\
\hline Residual error & 143 & 1.098 & 0.008 & & \\
\hline \multicolumn{6}{|l|}{ 25-51 mm scallops } \\
\hline Equality of slopes & 1 & 0.085 & 0.085 & 8.90 & 0.0034 \\
\hline Residual error & 133 & 1.277 & 0.010 & & \\
\hline
\end{tabular}

When the response after 15 min of recuperation was compared to the first response, wild and cultured scallops did not differ in the percent initial claps and percent clapping time, but cultured scallops showed a more complete recuperation of their initial clapping rate and of the initial maximum number of claps (Table 4).

Cultured and wild scallops did not differ in mean righting time $(\mathrm{p}=0.077 ; 27.1 \pm 3.5$ and $28.7 \pm 2.6 \mathrm{~min}$ [mean $\pm \mathrm{SE}$ ] for 35 to $45 \mathrm{~mm}$ cultured [ $\mathrm{n}=74$ ] and wild scallops [ $\mathrm{n}=72]$, respectively) and most scallops righted themselves within 50 min (Fig. 3a). The righting responses of larger individuals (shell height 45 to $55 \mathrm{~mm}$ ) were quite similar (Fig. 3b).

\section{Muscle biochemical composition and enzymatic activities}

Both total carbohydrate and total protein contents in the phasic muscle were markedly higher in cultured than in wild scallops (Table 5). Cultured scallops showed higher specific activities for phosphofructokinase and octopine dehydrogenase, both as $\mathrm{U} \mathrm{g}^{-1}$ muscle and $\mathrm{U} \mathrm{mg}^{-1}$ protein. The other enzymes showed similar activities for both groups. Given the larger size of the adductor muscle in cultured scallops, the total contents of all the enzymes measured were consistently higher in cultured scallops.

\section{Determinants of the escape responses}

Among the numerous biochemical and anatomical parameters we measured for each individual, few seemed linked to the performance in the escape responses (Table 6). Most variables were eliminated initially since they inflated the variance of the regression model. Hence, the shell masses, catch muscle masses, protein and carbohydrate content in the phasic muscle and the activities of the five enzymes considered (PFK, GP, CS, ODH, $\mathrm{AK}$ ) were submitted to multiple stepwise regressions in which each escape parameter was a dependent variable. Muscle carbohydrates and the activity of the $\mathrm{ODH}$ partially explained the total number of claps during the initial escape test. CS activity was also significantly associated with the maximal number of claps in a row. 
Table 3. Placopecten magellanicus. Mean clapping behavior (SE, $\mathrm{n}$ ) during escape responses by wild and cultured (35 to $45 \mathrm{~mm}$ ) sea scallops. p-values assigned according to 2-factor ANOVAs (origin and day of study) and show differences due to scallop origin

\begin{tabular}{|c|c|c|c|c|c|}
\hline Origin & Number of claps & $\begin{array}{l}\text { Clapping time } \\
\text { (min) }\end{array}$ & $\begin{array}{l}\text { Clapping rate } \\
\left(\text { claps min }{ }^{-1} \text { ) }\right.\end{array}$ & $\begin{array}{l}\text { Max number of } \\
\text { claps in a series }\end{array}$ & $\begin{array}{c}\text { Time spent closed } \\
(\min )^{\mathrm{b}}\end{array}$ \\
\hline \multicolumn{6}{|c|}{ Initial response } \\
\hline Cultured & $48.5(1.5,76)$ & $1.42(0.06,76)$ & $37.5(1.5,76)$ & $10.3(0.8,52)$ & $5.1(0.3,70)$ \\
\hline Wild & $44.2(1.0,76)$ & $0.90(0.02,76)$ & $50.7(1.2,76)$ & $11.2(0.6,52)$ & $6.5(0.3,70)$ \\
\hline $\mathrm{p}$ & 0.014 & $<0.0001$ & $<0.0001$ & 0.17 & 0.0006 \\
\hline \multicolumn{6}{|c|}{ Response after $15 \mathrm{~min}$ of recuperation ${ }^{\mathrm{c}}$} \\
\hline Cultured & $28.3(1.0,74)$ & $1.00(0.06,74)$ & $33.1(1.6,74)$ & $7.3(0.4,50)$ & - \\
\hline Wild & $23.7(1.1,72)$ & $0.66(0.05,72)$ & $39.9(1.3,72)$ & $5.8(0.3,50)$ & - \\
\hline $\mathrm{p}$ & 0.0041 & $<0.0001$ & 0.0010 & 0.0054 & - \\
\hline
\end{tabular}

Table 4. Placopecten magellanicus. Mean (SE, n) percentage (\%) of initial number of claps, clapping time, clapping rate and maximum number of claps in a series after 15 min recuperation from exhaustive escape responses by wild and cultured ( 35 to $45 \mathrm{~mm}$ ) sea scallops. Two cultured and 4 wild individuals were removed from the analyses because they did not clap after the 15 min recuperation period. Up to 4 scallops showing a recuperation beyond $200 \%$ were eliminated. p-values showing differences between wild and cultured scallops assigned according to 2-factor ANOVAs (origin and day of study)

\begin{tabular}{|lcccc|}
\hline Origin & \% initial number of claps & \% initial clapping time & \% initial clapping rate & $\begin{array}{c}\% \text { initial max number of } \\
\text { claps in a series }^{\mathrm{a}}\end{array}$ \\
\hline Cultured & $60.8(2.7,73)$ & $70.4(3.9,72)$ & $93.4(4.6,73)$ & $84.7(6.3,49)$ \\
Wild & $56.2(3.3,72)$ & $66.1(3.4,68)$ & $80.6(2.6,72)$ & $58.1(4.6,49)$ \\
$\mathrm{p}$ & 0.24 & 0.57 & 0.046 & 0.0013 \\
a Not measured for 24 individuals from each group on the first day of the experiment & \\
\hline
\end{tabular}
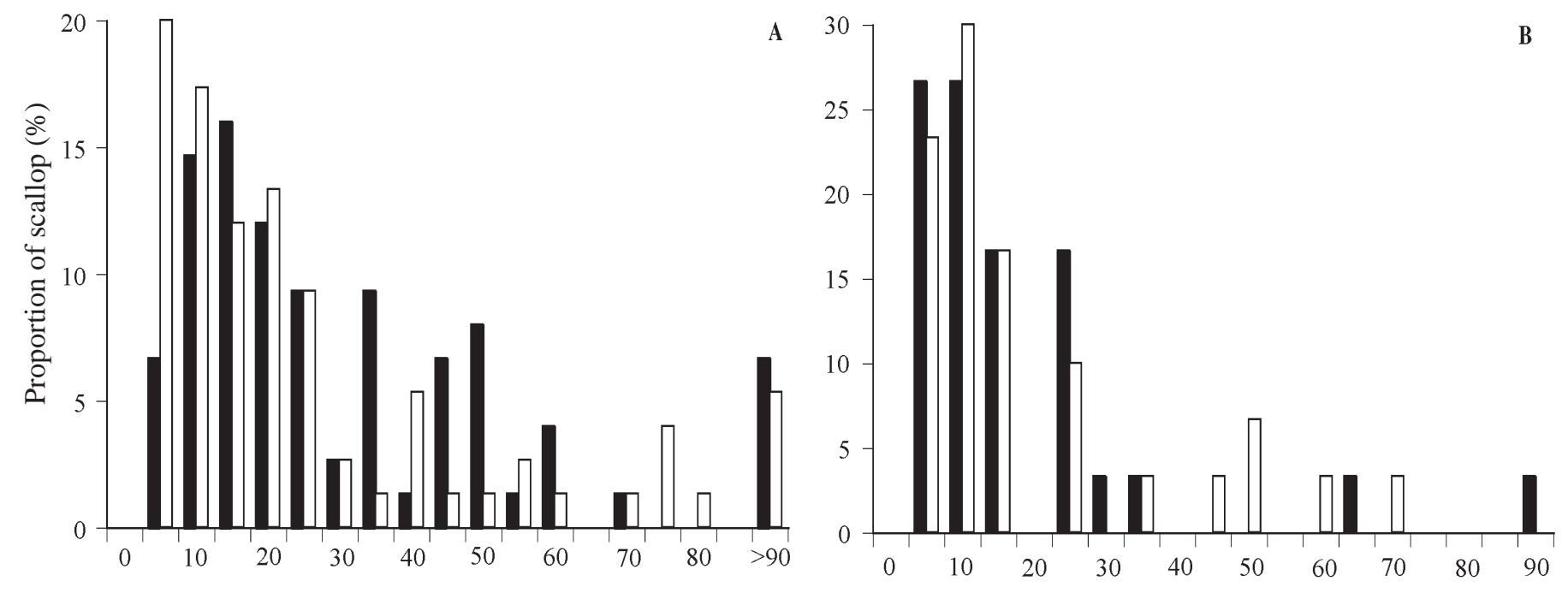

Time (min)

Fig. 3. Placopecten magellanicus. Righting time of wild and cultured sea scallops (A) Scallops with a shell height of 35 to $45 \mathrm{~mm}$, used for all comparisons; $\mathrm{n}=75$ for both wild and cultured scallops. (B) Scallops with a shell height of 45 to $55 \mathrm{~mm}$; $\mathrm{n}=30 \mathrm{for}$ both wild and cultured scallops. Solid bars correspond to wild scallops; open bars correspond to cultured scallops 
Table 5. Placopecten magellanicus. Mean (SE, n) biochemical reserves and maximal enzymatic activities of phasic adductor muscle from wild and cultured ( 35 to $45 \mathrm{~mm}$ ) sea scallops. p-values are from Student's $t$-tests, or from Mann-Whitney $U$-tests when the data were not normal

\begin{tabular}{|c|c|c|c|c|}
\hline Variable & Units & Cultured & Wild & $\mathrm{p}$ \\
\hline Carbohydrates & $\begin{array}{l}\mathrm{mg} \mathrm{g}^{-1} \text { wet muscle } \\
\mathrm{mg} \mathrm{muscle}^{-1}\end{array}$ & $\begin{array}{l}17.8(0.6,76) \\
17.8(0.8,76)\end{array}$ & $\begin{array}{l}3.3(0.1,76) \\
2.0(0.1,76)\end{array}$ & $\begin{array}{l}<0.0001 \\
<0.0001\end{array}$ \\
\hline Proteins & $\begin{array}{l}\mathrm{mg} \mathrm{g}^{-1} \text { wet muscle } \\
\mathrm{mg} \mathrm{muscle}^{-1}\end{array}$ & $\begin{array}{l}133.2(1.8,76) \\
131.2(3.9,76)\end{array}$ & $\begin{array}{r}121.1(1.6,76) \\
73.0(2.2,76)\end{array}$ & $\begin{array}{l}<0.0001 \\
<0.0001\end{array}$ \\
\hline Glycogen phosphorylase & $\begin{array}{c}\mathrm{U} \mathrm{g}^{-1} \text { wet muscle } \\
\mathrm{U} \times 10^{-3} \mathrm{mg}^{-1} \text { protein } \\
\text { Total U }\end{array}$ & $\begin{array}{l}0.75(0.05,28) \\
5.20(0.40,28) \\
0.73(0.06,28)\end{array}$ & $\begin{array}{l}0.62(0.03,27) \\
4.69(0.25,27) \\
0.39(0.03,27)\end{array}$ & $\begin{aligned} & 0.17 \\
& 0.84 \\
< & 0.0001\end{aligned}$ \\
\hline Phosphofructokinase & $\begin{array}{c}\mathrm{U} \mathrm{g}^{-1} \text { wet muscle } \\
\mathrm{U} \times 10^{-3} \mathrm{mg}^{-1} \text { protein } \\
\text { Total } \mathrm{U}\end{array}$ & $\begin{array}{l}0.92(0.03,28) \\
6.34(0.21,28) \\
0.90(0.04,28)\end{array}$ & $\begin{array}{l}0.73(0.04,28) \\
5.53(0.27,28) \\
0.46(0.03,28)\end{array}$ & $\begin{array}{r}<0.0001 \\
0.0048 \\
<0.0001\end{array}$ \\
\hline Octopine dehydrogenase & $\begin{array}{c}\mathrm{U} \mathrm{g}^{-1} \text { wet muscle } \\
\mathrm{U} \times 10^{-3} \mathrm{mg}^{-1} \text { protein } \\
\text { Total } \mathrm{U}\end{array}$ & $\begin{array}{c}40.5(1.6,28) \\
281(12,28) \\
40.3(2.4,28)\end{array}$ & $\begin{array}{l}29.9(1.2,28) \\
226(9,28) \\
18.6(1.1,28)\end{array}$ & $\begin{array}{r}<0.0001 \\
0.0017 \\
<0.0001\end{array}$ \\
\hline Arginine kinase & $\begin{array}{c}\mathrm{U} \mathrm{g}^{-1} \text { wet muscle } \\
\mathrm{U} \mathrm{mg}^{-1} \text { protein } \\
\text { Total U }\end{array}$ & $\begin{array}{l}414(27,28) \\
2.86(0.19,28) \\
410(34,28)\end{array}$ & $\begin{array}{l}372(19,28) \\
2.82(0.15,28) \\
230(14,28)\end{array}$ & $\begin{aligned} & 0.80 \\
& 0.23 \\
< & 0.0001\end{aligned}$ \\
\hline Citrate synthase & $\begin{array}{c}\mathrm{U} \mathrm{g}^{-1} \text { wet muscle } \\
\mathrm{U} \times 10^{-3} \mathrm{mg}^{-1} \text { protein } \\
\text { Total } \mathrm{U}\end{array}$ & $\begin{array}{r}2.40(0.05,28) \\
16.59(0.44,28) \\
2.36(0.10,28)\end{array}$ & $\begin{array}{r}2.43(0.07,28) \\
18.38(0.52,28) \\
1.50(0.06,28)\end{array}$ & $\begin{array}{l}0.63 \\
0.012 \\
<0.0001\end{array}$ \\
\hline
\end{tabular}

\section{DISCUSSION}

Favorable conditions during suspension culture enhance growth of scallops. The cultured scallops we studied had been grown at low density $(<30 \%$ of floor coverage, see Ventilla 1982), in a lagoon where temperature and food supply were higher than on the seabed (Cliche et al. unpubl.). Moreover, the density of fouling organisms was low at harvesting and no other species were present inside the pearl nets. Thus after $\sim 2$ yr growth, in late August 1999, when animals of the same shell height range were compared, cultured scallops had greater soft tissue masses (digestive gland, muscle, remaining soft tissues) and better condition indices than wild scallops. This result corroborates the finding by Naidu et al. (1989) that sea scallops cultured in suspension grow faster than their wild counterparts. Sea scallops of the size range we used can reach sexual maturity; their reproductive investment may rise to $20 \%$ (annual gamete production divided by gamete and somatic tissue production) by their second year (MacDonald 1984, Black et al. 1993). We sampled the scallops in August, a time of gametogenesis (Parsons et al. 1992, Bonardelli et al. 1996). If reproductive effort was greater in wild than cultured scallops, this could have reduced the mass of tissues, notably muscle, relative to those of cultured scallops, as found by Rodhouse et al. (1984) in a comparison of mussels on the shore and from suspended culture. However, the experimental scallops, both wild and cultured, had a relatively small and translucent gonad, which prevented sex determination. This suggests that reproductive effort was insignificant.

MacDonald (1986) reported that Placopecten magellanicus grown on the bottom had heavier shells than suspension cultured scallops of a given shell height. Studies of the scallop Crassadoma gigantea (30 to $80 \mathrm{~mm}$ ) (MacDonald \& Bourne 1989) and the mussel Mytilus edulis (Rodhouse et al. 1984) also show that wild individuals from the bottom have heavier shells than those in suspended culture. While the shell heights and masses of the wild and cultured scallops were the same, the other linear dimensions and the volume enclosed by the shells of wild scallops were smaller, indicating that the shells of wild scallops were either thicker or denser than the shells of cultured scallops. Thus, the shells of wild scallops resisted greater pressures. This difference in shell strength is consistent with the suggestion that wild individuals are better protected against grasping predators such as crabs. As crabs favor prey with shorter handling times, they may prefer cultured scallops (Jubb et al. 1983, Boulding 1984, SanchezSalazar et al. 1987, Juanes 1992). Morphological responses to a perceived risk of predation can improve the fitness of some marine invertebrates. Thus, exposure of Mytilus edulis to Asterias rubens led to the development of more compact and rounded shells, without changes in shell mass (Reimer et al. 1995, Reimer \& Tedengren 1996). The mussels also secreted 


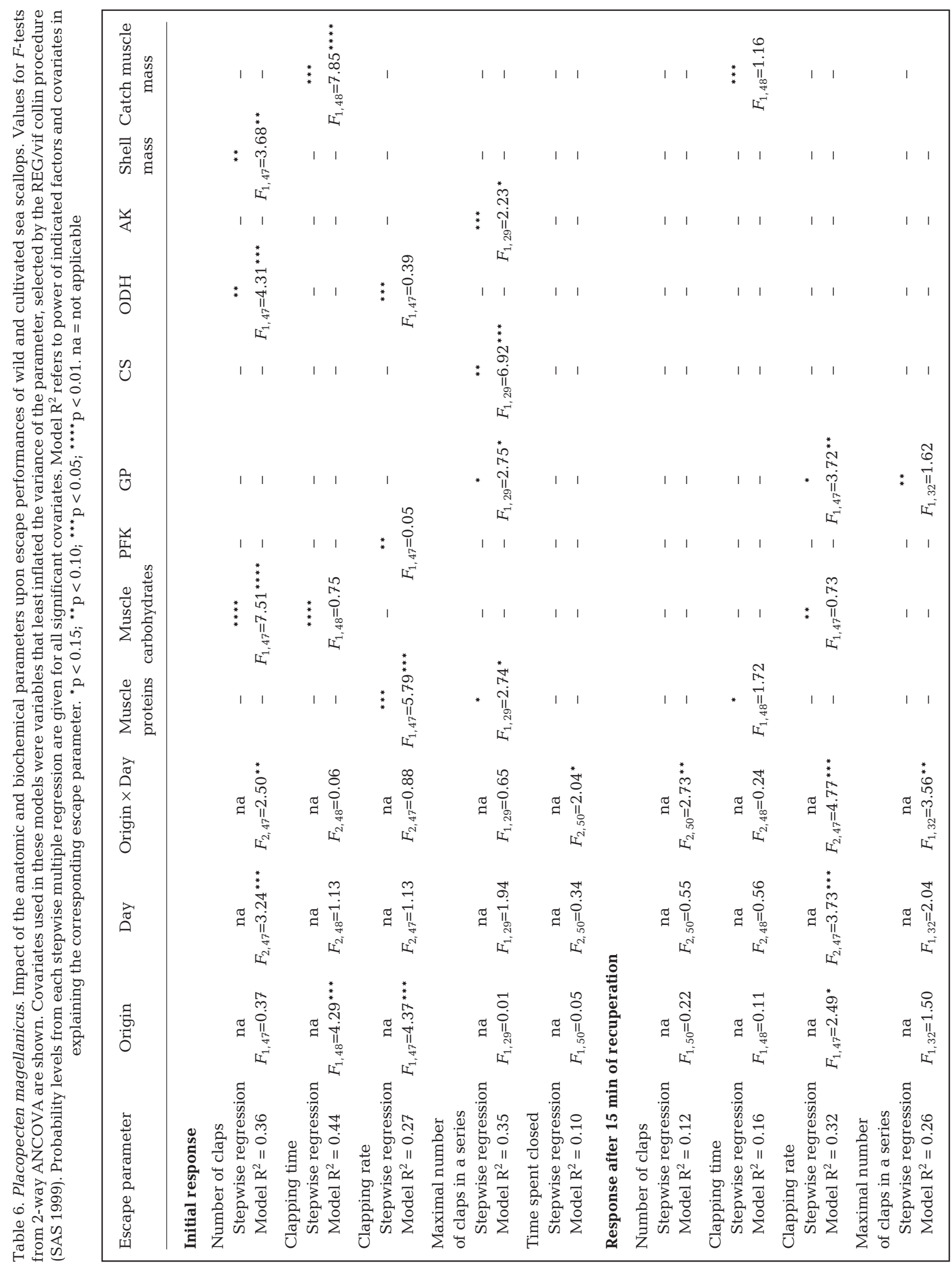


more, shorter and thicker byssus threads when placed in water in which a predatory crab had been placed (Côté 1995). Furthermore, slow growth can enhance shell thickness and change shell shape in Mytilus edulis (Seed 1968). Chemical cues of crab activity foraging induce development of shell features which help resist predators in the juvenile gastropod Nucella lapillus (Palmer 1990). A predatory snail induces bent-over growth in the barnacle Chthamalus anisopoma, reducing its vulnerability (Lively 1986). Hence, predators on natural grounds and slower growth may have stimulated a greater investment in shell strength (mass/thickness) in wild scallops, or may have eliminated scallops with thinner shells. The rock crab Cancer irroratus is an important predator of P. magellanicus and adjusts its predation rates to the availability of juvenile scallops at the seeding sites, thus leading to a density-dependent mortality of scallops (Barbeau et al. 1996). Since $P$. magellanicus often closes its valves in response to encounters with crabs (Barbeau \& Scheibling 1994a), the lower resistance to crushing of the shell of cultured scallops may contribute to high mortality in seeding operations.

The higher clapping rate of wild scallops may favor their survival when faced with foraging asteroids, as a vigorous clapping to an initial contact with these nonvisual predators may facilitate escape. Survival should be increased by decreased encounter rates with predators (Barbeau \& Scheibling 1994a-c). Nonetheless, the cultured scallops clapped more and longer than wild scallops both during their initial escape response and during the response after $15 \mathrm{~min}$ of recuperation. Also, the period of valve closure during recuperation was shorter for cultured than wild scallops. Clearly, cultured scallops mounted a strong escape response to starfish. Predator-conditioned juvenile Buccinum undatum show increased responsiveness (high intensity escape response) to their natural predator Leptasterias polaris (Rochette et al. 1998). Possibly, exposure of wild scallops to starfish in their natural habitat favored the development of a higher clapping rate. Alternately, predation on scallops with lower clapping rates may have led to the difference between wild and cultured scallops. Methodology is unlikely to be the cause of these differences, since we always concluded a test by stimulating the scallop's best area for triggering a swim response: the byssal notch on the right valve, adjacent to the anterior ear region (Ordzie \& Garofalo 1980, Wilkens 1981). Further, a reduction in the ability to escape predators has been reported to result from stress caused by the physical impact of dredges (Jenkins \& Brand 2001). Our wild Placopecten magellanicus, sampled by dredging, seemed undamaged and were tested after being maintained for $7 \mathrm{~d}$ in the laboratory. However, if the physiological status of the wild scallops was still affected at the time of the escape tests, their performance may have been lower than that of unstressed wild scallops.

Conditioning to moderately high water temperature can enhance shell growth, adductor muscle condition, and energy reserves in juvenile Placopecten magellanicus (Kleinman et al. 1996). The higher reserve levels and soft tissue contents of cultured scallops are likely linked with their greater number of claps, longer clapping period and faster recuperation of clapping performance. The adductor muscles of cultured scallops were larger (both absolute and relative masses), had higher carbohydrate and protein levels and higher $\mathrm{ODH}$ and PFK activities than those from wild scallops. The shorter period of valve closure in cultured scallops would have facilitated aerobic recuperation of intracellular metabolites after the initial exhausting escape response (Brokordt et al. 2000a). The shorter valve closure may well be linked with the higher catalytic capacity of enzymes in anaerobic glycolysis. Anaerobic glycolysis produces ATP both during the final portion of escape responses and during the glycolytic recovery period (Thompson et al. 1980, Livingstone et al. 1981). The combination of a higher capacity for anaerobic recuperation and a longer aerobic recuperation allowed the cultured scallops to out-perform wild scallops during the second escape response.

Both muscle carbohydrate and protein levels were similar to values measured in adult Chlamys islandica, a sympatric species found in the northern Gulf of St. Lawrence (Brokordt et al. 2000a). The levels of energetic reserves we measured in the muscle were slightly lower than those observed in other scallop species (Martinez 1991, Boadas et al. 1997, Brokordt et al. 2000b, Lodeiros et al. 2001). Since high swimming frequency decreases carbohydrate reserves from adductor muscle in juvenile Placopecten magellanicus (Kleinman et al. 1996), the escape responses coupled with a lack of food between escape responses and dissections could explain the somewhat lower carbohydrate levels observed in our study.

The glycolytic capacity in the phasic muscle of adult Placopecten magellanicus (de Zwaan et al. 1980) seems slightly greater than that of juveniles from our study. Thermal effects are likely to account for much of this difference since enzyme activities were measured at $25^{\circ} \mathrm{C}$ by de Zwaan et al. (1980), whereas our determinations were made at $12.5^{\circ} \mathrm{C}$. The maximal enzymatic capacities measured by de Zwaan et al. (1980) ranged from 1.58 to 1.82 and from 2.34 to $3.04 \mathrm{U} \mathrm{g}^{-1}$ wet muscle mass for GP and PFK, respectively. Sizedependent increases in the activities of glycolytic enzymes as observed in the bay scallop's adductor muscle (Garcia-Esquivel \& Bricelj 1993) and in white skeletal fish muscle (Somero \& Childress 1990) could 
also contribute to the difference between adult and juvenile GP-PFK activity.

Whereas performance during escape responses differed between wild and cultured scallops, the righting responses did not. Our measurements of escape responses were carried out individually, whereas the righting responses were monitored simultaneously for each group of scallops. The activities of neighboring scallops influence the behavior of a given scallop (Brand 1991), and in future studies on righting responses, individual measurements should be carried to prevent pseudoreplication (Hurlbert 1984).

Our attempt to explain escape performances according to the numerous parameters we have measured remained more or less in vain. Only muscle carbohydrates and $\mathrm{ODH}$ and CS activities showed links with escape response performance. No correlations were observed between the escape performance and the righting responses. Although muscle substrates and metabolic pathways must be used during escape responses, the weak correlations we observed suggest that these parameters are not limiting escape responses. Elucidation of the physiological determinants of behavior showing marked inter-individual variability may require study of an even greater number of subjects or a wider range of physiological parameters.

In conclusion, cultured and wild juvenile Placopecten magellanicus showed strong responses to encounters with starfish, with cultured scallops clapping more and longer than wild scallops. On the other hand, the clapping rate was higher for wild scallops, both initially and after 15 min of recuperation from the first exhausting escape response. The shell of wild scallops was also significantly stronger than that of cultured scallops. Since crabs can decimate juvenile scallop populations more quickly than starfish (Barbeau \& Scheibling 1994a, Cliche et al. 1994, Barbeau et al. 1996, Nadeau \& Cliche 1998), future studies should examine the mechanisms enhancing scallop shell strength and also explore ways of reducing crab abundance on the reseeding grounds. The greater shell strength and clapping intensity of wild scallops could facilitate their survival during the period of high juvenile mortality.

Acknowledgements. We thank C. Cyr, F. Aucoin and M. Guay for laboratory assistance and Diego Mantovani for facilitating our measurements of shell strength. We are also grateful to $M$. Giguère for his aid with the sampling of wild scallops, to H. Paradis and R. Côté for their statistical support and to J. H. Himmelman and B. Myrand for helpful comments on the paper. This study was supported by funds from MAPAQ (Ministère de l'Agriculture des Pêcheries et de l'Alimentation du Québec) to M.L. and H.G. and by an operating grant from the NSERC to H.G.

\section{LITERATURE CITED}

Barbeau MA, Scheibling RE (1994a) Behavioral mechanisms of prey size selection by sea stars (Asterias vulgaris Verrill) and crabs (Cancer irroratus Say) preying on juvenile sea scallops (Placopecten magellanicus Gmelin). J Exp Mar Biol Ecol 180:103-136

Barbeau MA, Scheibling RE (1994b) Procedural effects of prey tethering experiments: predation of juvenile scallops by crabs and sea stars. Mar Ecol Prog Ser 111:305-310

Barbeau MA, Scheibling RE (1994c) Temperature effects on predation of juvenile sea scallops (Placopecten magellanicus Gmelin) by sea stars (Asterias vulgaris Verrill) and crabs (Cancer irroratus Say). J Exp Mar Biol Ecol 182: $27-47$

Barbeau MA, Hatcher BG, Scheibling RE, Hennigar AW, Taylor LH, Risk AC (1996) Dynamics of juvenile sea scallop (Placopecten magellanicus) and their predators in bottom seeding trials in Lunenburg Bay, Nova Scotia. Can J Fish Aquat Sci 53:2494-2512

Black GAP, Mohn RK, Robert G, Tremblay MJ (1993) Atlas of the biology and distribution of the sea scallop Placopecten magellanicus and Iceland scallop Chlamys islandica in the Northwest Atlantic. Can Tech Rep Fish Aquat Sci 1915

Boadas MA, Nusetti O, Mundarain F, Lodeiros C, Guderley HE (1997) Seasonal variation in the properties of muscle mitochondria from the tropical scallop Euvola (Pecten) ziczac. Mar Biol 128:247-255

Bonardelli JC, Himmelman JH, Drinkwater K (1996) Relation of spawning of the giant scallop, Placopecten magellanicus, to temperature fluctuations during downwelling events. Mar Biol 124:637-649

Boulding EG (1984) Crab-resistant features of shells of burrowing bivalves: decreasing vulnerability by increasing handling time. J Exp Mar Biol Ecol 76:201-223

Brand AR (1991) Scallop ecology: distributions and behaviour. In: Shumway SE (ed) Scallops: biology, ecology and aquaculture. Elsevier, New York, p 517-584

Brokordt KB, Himmelman JH, Guderley HE (2000a) Effect of reproduction on escape responses and muscle metabolic capacities in the scallop Chlamys islandica Müller 1776. J Exp Mar Biol Ecol 251:205-225

Brokordt KB, Himmelman JH, Nusetti OA, Guderley HE (2000b) Reproductive investment reduces recuperation from exhaustive escape activity in the tropical scallop Euvola zizac. Mar Biol 137:857-865

Caddy JF (1968) Underwater observations on scallop (Placopecten magellanicus) behaviour and drag efficiency. J Fish Res Board Can 25:2123-2141

Carsen AE, Hatcher BG, Scheibling RE (1996) Effect of flow velocity and body size on swimming trajectories of sea scallops, Placopecten magellanicus (Gmelin): a comparison of laboratory and field measurements. J Exp Mar Biol Ecol 203:223-243

Cliche G, Giguère $M$ (1998) Final report of the research program on scallop culture and restocking (REPERE), 1990-1997. Can Ind Rep Fish Aquat Sci 247

Cliche G, Giguère M, Vigneau S (1994) Dispersal and mortality of sea scallops, Placopecten magellanicus (Gmelin 1791), seeded on the sea bottom off Iles-de-la-Madeleine. J Shellfish Res 13:565-570

Côté IM (1995) Effects of predatory crab effluent on byssus production in mussels. J Exp Mar Biol Ecol 188:233-241

Dadswell MJ, Weihs D (1990) Size-related hydrodynamic characteristics of the giant scallop, Placopecten magellanicus (Bivalvia: Pectinidae). Can J Zool 68:778-785

de Zwaan A, Thompson RJ, Livingstone DR (1980) Physiolog- 
ical and biochemical aspects of the valve snap and valve closure responses in the giant scallop Placopecten magellanicus: 2. Biochemistry. J Comp Physiol 137:105-114

Dubois M, Gilles KA, Hamilton JK, Rebers PA, Smith F (1956) Colorimetric method for determination of sugars and related substances. Anal Biochem 28:350-356

Elner RW, Jamieson GS (1979) Predation of sea scallops, Placopecten magellanicus, by the rock crab, Cancer irroratus, and the American lobster, Homarus americanus. J Fish Res Board Can 36:537-543

Garcia-Esquivel Z, Bricelj VM (1993) Ontogenic changes in microhabitat distribution of juvenile bay scallops, Argopecten irradians irradians (L.), in eelgrass beds, and their potential significance to early recruitment. Biol Bull (Woods Hole) 185:42-55

Gould SJ (1971) Muscular mechanics and the ontogeny of swimming in scallops. Palaeontology 14:61-94

Hatcher BG, Scheibling RE, Barbeau MA, Hennigar AW, Taylor LH, Windust AJ (1996) Dispersion and mortality of a population of sea scallop (Placopecten magellanicus) seeded in a tidal channel. Can J Fish Aquat Sci 53:38-54

Haugum GA, Strand O, Minchin D (1999) Are cultivated scallops wimps? In: Proc 12th Int Pectinid Workshop. Institute of Marine Research Bergen, Norway, 5-11 May 1999, p 92-93

Havel JE (1987) Predator-induced defenses: a review. In: Kerfoot WC, Sih A (eds) Predation: direct and indirect impacts on aquatic communities. University Press of New England, Hanover, p 263-278

Hurlbert SH (1984) Pseudoreplication and the design of ecological field experiments. Ecol Monogr 54:187-212

Jenkins S, Brand A (2001) The effect of dredge capture on the escape response of the great scallop, Pecten maximus (L.): implications for the survival of undersized discards. J Exp Mar Biol Ecol 266:33-50

Juanes F (1992) Why do decapod crustaceans prefer smallsized molluscan prey? Mar Ecol Prog Ser 87:239-249

Jubb CA, Hughes RN, Rheinallt TA (1983) Behavioral mechanisms of size-selection by crabs, Carcinus maenas, feeding on mussels, Mytilus edulis. J Exp Mar Biol Ecol 66:81-88

Kleinman S, Hatcher BG, Scheibling RE (1996) Growth and content of energy reserves in juvenile sea scallops, Placopecten magellanicus, as a function of swimming frequency and water temperature in the laboratory. Mar Biol 124:629-635

Lafrance ML, Guderley H, Cliche G (2002) Low temperature, but not air exposure slows the recuperation of juvenile scallops, Placopecten magellanicus, from exhausting escape responses. J Shellfish Res 21:605-618

Lively CM (1986) Predator-induced shell dimorphism in the acorn barnacle Chthamalus anisopoma. Evolution 40: 232-242

Livingstone DR, de Zwaan A, Thompson RJ (1981) Aerobic metabolism, octopine production and phosphoarginine as sources of energy in the phasic and catch adductor muscles of the giant scallop, Placopecten magellanicus, during swimming and the subsequent recovery period. Comp Biochem Physiol B 70:35-44

Lodeiros CJ, Rengel JJ, Guderley HE, Nusetti O, Himmelman JH (2001) Biochemical composition and energy allocation in the tropical scallop Lyropecten (Nodipecten) nodosus during the months leading up to and following the development of gonads. Aquaculture 199:63-72

MacDonald BA (1984) The partitioning of energy between growth and reproduction in the giant scallop, Placopecten magellanicus (Gmelin). PhD thesis, Memorial University, St. John's, Newfoundland
MacDonald BA (1986) Production and resource partitioning in the giant scallop Placopecten magellanicus grown on the bottom and in suspended culture. Mar Ecol Prog Ser 34:79-86

MacDonald BA, Bourne NF (1989) Growth of the purplehinge rock scallop, Crassadoma gigantea Gray, 1825 under natural conditions and those associated with suspended culture. J Shellfish Res 8:179-186

Manuel JL, Dadswell MJ (1991) Swimming behavior of juvenile giant scallop, Placopecten magellanicus, in relation to size and temperature. Can J Zool 69:2250-2254

Manuel JL, Dadswell MJ (1993) Swimming of juvenile sea scallops, Placopecten magellanicus (Gmelin): a minimum size for effective swimming? J Exp Mar Biol Ecol 174: $137-175$

Martinez G (1991) Seasonal variation in biochemical composition of three size classes of the Chilean scallop Argopecten purpuratus Lamarck, 1819. Veliger 34: 335-343

Minchin D (1991) Decapod predation and the sowing of the scallop, Pecten maximus (Linnaeus, 1758). In: Shumway SE, Sandifer PA (eds) An international compendium of scallop biology and culture. World Aquaculture Society, Baton Rouge, LA, p 191-197

Nadeau M, Cliche G (1998) Predation of juvenile sea scallops (Placopecten magellanicus) by crabs (Cancer irroratus and Hyas sp.) and starfish (Asterias vulgaris, Leptasterias polaris, and Crossaster papposus). J Shellfish Res 17: 905-910

Naidu KS, Fournier R, Marsot P, Worms J (1989) Culture of the sea scallop, Placopecten magellanicus: opportunities and constraints. In: Boghen AD (ed) Cold-water aquaculture in Atlantic Canada. Canadian Institute for Research on Regional Development, Moncton, New Brunswick, p 211-239

Ordzie CJ, Garofalo GC (1980) Behavioral recognition of molluscan and echinoderm predators by the bay scallop, Argopecten irradians, at 2 temperatures. J Exp Mar Biol Ecol 43:29-37

Palmer AR (1990) Effect of crab effluent and scent of damaged conspecifics on feeding, growth, and shell morphology of the Atlantic dog whelk Nucella lapillus (L.). Hydrobiol 193:155-182

Parsons GJ, Robinson SMC, Chandler RA, Davidson LA, Lanteigne M, Dadswell JJ (1992) Intra-annual and longterm patterns in the reproductive cycle of giant scallops Placopecten magellanicus (Bivalvia: Pectinidae) from Passamaquoddy Bay, New Brunswick, Canada. Mar Ecol Prog Ser 80:203-214

Reimer O, Olsson B, Tedengren M (1995) Growth, physiological rates and behaviour of Mytilus edulis exposed to the predator Asterias rubens. Mar Behav Physiol 25: 233-244

Reimer O, Tedengren M (1996) Phenotypical improvement of morphological defences in the mussel Mytilus edulis induced by exposure to the predator Asterias rubens. Oikos 75:383-390

Rochette R, Arsenault DJ, Justome B, Himmelman JH (1998) Chemically-mediated predator-recognition learning in a marine gastropod. Ecoscience 5:353-360

Rodhouse PG, Roden CM, Hensey MP, Ryan TH (1984) Resource allocation in Mytilus edulis on the shore and in suspended culture. Mar Biol 84:27-34

Sanchez-Salazar ME, Griffiths CL, Seed R (1987) The effect of size and temperature on the predation of cockles Cerastoderma edule (L.) by the shore crab Carcinus maenas (L.). J Exp Mar Biol Ecol 111:181-194 
SAS (1999) SAS/STAT user's guide, release 8.02 edn. SAS Institute Press, Cary, NC

Seed R (1968) Factors influencing shell shape in the mussel Mytilus edulis. J Mar Biol Assoc UK 48:561-584

Smith PK, Krohn RI, Hermanson GT, Mallia AK, Gartner FH and 5 others (1985) Measurement of protein using bicinchoninic acid. Anal Biochem 150:76-85

Snedecor GW, Cochran WG (1989) Statistical methods, 8th edn. Iowa State University Press, Ames, IA

Somero GN, Childress JJ (1990) Scaling of ATP-supplying enzymes, myofibrillar proteins and buffering capacity in fish muscle: relationship to locomotory habit. J Exp Biol 149:319-334

Stewart JM, Brass ME, Carlin RC, Black H (1992) Maximal enzyme activities of energy production pathways in the heart, hepatopancreas, and white muscle of the giant scallop (Placopecten magellanicus) and lobster (Homarus americanus). Can J Zool 70:720-724

Thompson RJ, Livingstone DR, de Zwaan A (1980) Physiological and biochemical aspects of the valve snap

Editorial responsibility: John Lawrence (Contributing Editor), Tampa, Florida, USA and valve closure responses in the giant scallop Placopecten magellanicus: 1. Physiology. J Comp Physiol 137: 97-104

Tremblay J (1988) A summary of the proceedings of the Halifax Sea Scallop Workshop, August 13-14, 1987. Can Tech Rep Fish Aquat Sci 1605

Ventilla RF (1982) The scallop industry in Japan. In: Blaxter JHS, Russell FS, Yonge M (eds) Advances in marine biology 20:309-382

Wilkens LA (1981) Neurobiology of the scallop (Pecten ziczac):1. Starfish-mediated escape behaviors. Proc R Soc Lond B 211:341-372

Wilkens LA (1991) Neurobiology and behavior of the scallop. In: Shumway SE (ed) Scallops: biology, ecology and aquaculture. Elsevier, New York, p 429-469

Young-Lai WW, Aiken DE (1986) Biology and culture of the giant scallop, Placopecten magellanicus: a review. Can Tech Rep Fish Aquat Sci 1478

Zar JH (1984) Biostatistical analysis, 2nd edn. Prentice-Hall, Englewood Cliffs, NJ

Submitted: September 10, 2002; Accepted: November 11, 2002 Proofs received from author(s): March 4, 2003 